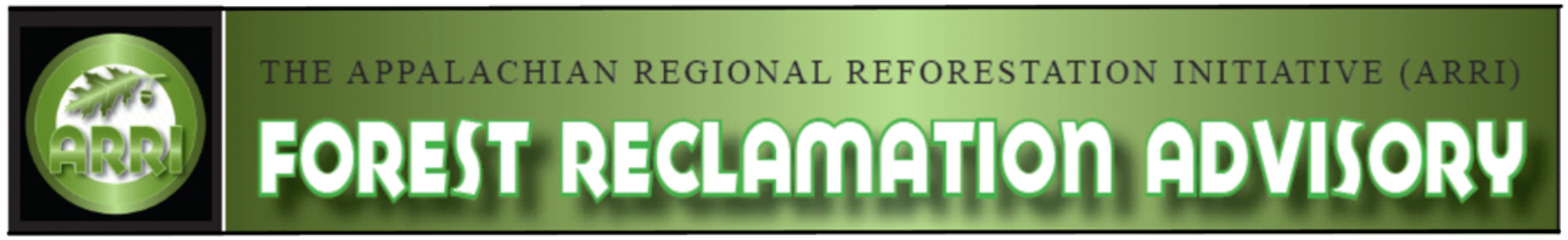

Forest Reclamation Advisory No. 14

February 2017

\title{
RE-ESTABLISHING POLLINATOR HABITAT ON MINED LANDS USING THE FORESTRY RECLAMATION APPROACH
}

Tammy Horn, Patrick Angel, Carl Zipper, Michael Ulyshen, Michael French, Jim Burger, Mary Beth Adams

Pollinators are animals that play an essential role in the reproduction of many plants by transferring genetic material, in the form of pollen, from male to female flower parts. Because pollinator communities are under threat both in the US and worldwide, there is great interest in incorporating the needs of pollinators into habitat restoration plans. Forests provide many important resources such as nectar and pollen throughout the warmweather seasons as well as critical nesting habitats. This Advisory describes mine reforestation strategies that can encourage and support pollinator conservation in the eastern US. We also provide background information concerning pollinators and their conservation needs.

\section{Why are Pollinators Important?}

At least 80 percent of the world's more than 300,000 flowering plant species rely on pollinators such as bees, butterflies, moths, flies, wasps and beetles to aid in reproduction (National Research Council 2007; Ollerton et al. 2011 ). Since flowering species are rooted in place, pollinators transfer pollen between plants, thus ensuring that pollenproducing species are able to produce live seed. In return, the insects gain nutrition from pollen and nectars. Every year a honey bee colony consumes between 35 to $\mathbf{7 5}$ pounds of pollen and up to 125 pounds of nectar.

It is hard to overstate the importance of pollinating insects to the agricultural systems humans depend on for food and other products. Pollinators account for $\mathbf{\$ 1 5 . 2}$ billion worth of agricultural productivity for crops such as almonds. This estimate, however, does not take into consideration the full value of commodities that indirectly benefit from pollination, such as cattle, which are dependent on clover and alfalfa (Calderone 2012). The importance of pollinators for ensuring food supplies is well known, but they also perform other important ecosystem functions such as setting seed for many wildflowers and other plants that occur in forests. A large number of forest tree species depend on the services of pollinators, including many tree species of concern to the Appalachian Regional Reforestation Initiative (ARRI).

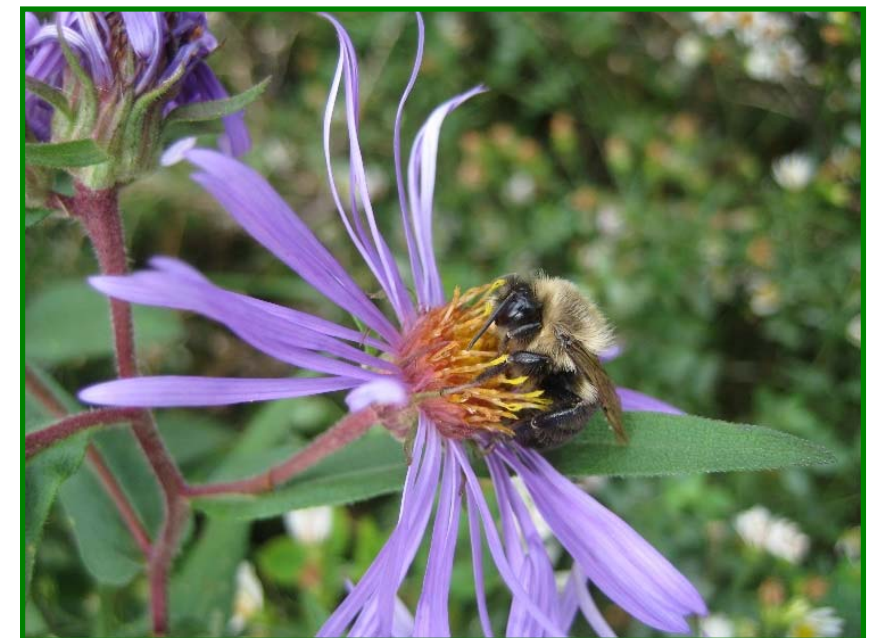

Figure 1. A small bumble bee (Bombus vagans) on an aster flower growing on a surface mine in Elk County, PA. Photo by Michael French.

\section{Pollinators Under Threat}

Honey bees are considered the "workhorse" of agricultural pollinators, both in the U.S. (where they were introduced from Europe in the $17^{\text {th }}$ century) and worldwide. Honey bees are challenged today by parasites and pathogens, chemical use in agriculture, and by habitat loss/degradation. A serious biological threat to honey bees is an Asian parasite called varroa mite (NRC 2007). Moreover, large areas of forest ecosystems that formerly served as habitat for honey bees have been lost to various kinds of development, including mining (Sayler 2008, Drummond and Loveland 2010). Declines in many pollinator groups are due to habitat loss, fragmentation, and deterioration (NRC 2007). 
Given the many threats facing honey bees, it is fortunate that we are not entirely dependent on this single species for our pollination needs. There are approximately 4000 species of native bees in North America (Moisset and Buchman 2011 ), for example, and these insects are also highly effective at pollinating plants in both natural and agricultural systems. Other native North American pollinators include butterflies and moths, flies, wasps and some vertebrate species like hummingbirds and bats. Recent research has documented declines of pollinators, both globally and in North America, and identifies a number of potential causes including environmental stressors such as pesticides, non-native invasive plants that displace native pollen-producing species, viruses and other pathogens and habitat loss /Goulson et al. 2015, Kearns and Inouye 1997, Cane and Tepedino 2001, Potts et al. 2010).

In Appalachia, forest loss due to surface mining and other disturbances results in less pollinator habitat. In recent decades, more than one million acres of forests have been mined and replaced with non-forest vegetation that often includes significant presence by non-native plants (Zipper et al. 2011 ; Oliphant et al. 2016). Displacement of native plant communities by non-native exotics is often unfavorable to pollinators (Hanula et al. 2016). Returning active and legacy surface mines to healthy, productive forests by using the Forestry Reclamation Approach (FRA) can help conserve these important pollinators.

\section{FRA and Pollinator Habitat Needs}

The FRA is a method for reclaiming coal-mined land to forest (Burger et al. 2005; Forest Reclamation Advisory No. 2) and is based on knowledge gained from both scientific research and experience. The FRA can achieve cost-effective regulatory compliance for coal operators while creating productive forests that generate value for their owners, provide environmental services, and create habitat that benefits pollinators.

Bees and other pollinators require habitats that supply resources that are essential to their life processes. These resources include the following:

- water, which is important for proper hive thermoregulation and nutritional preparation;

- floral hosts that supply pollen and nectar matched to a given species and blooming periods that meet the species' needs;

- nest-building materials consisting of plants and soils;
- nesting substrates, such as soils with organic materials, living plants, and dead plants such as decaying woody debris with cavities.

Because pollinators are so diverse in their habitat requirements, the National Research Council (2007) recommends conserving and restoring diverse plant communities and conserving existing habitats. The FRA can be applied as a means of creating habitat for pollinators and other animals that is similar to pre-mining habitat.

A primary habitat requirement of pollinators is the presence of a variety of flowering plants that provide nectar and pollen resources throughout the growing season. Reclamation using the FRA presents an opportunity to initiate plant community development from bare ground, with the goal of establishing a diversity of flowering tree, shrub, and herbaceous plants that are pollinator-friendly.

Also, research indicates that bees are especially sensitive to certain pesticides that are used commonly in agricultural and residential settings when trees are in bloom. Thus, reclaimed mine sites are excellent candidates for establishing healthy pollinator habitat because of the minimal use of agricultural chemicals associated with the reclamation process.

Restoration of pollinator habitat can be yet one more measure of success for coal companies seeking to demonstrate environmental stewardship through reclamation practices. Such habitat can also provide landowners with gainful income and aid economic development in nearby communities by supporting opportunities for commercial beekeeping (Box 1).

Below, we recommend methods for applying the FRA with the intent of restoring habitat conditions that are favorable to pollinators.

\section{Guidelines for Pollinator Habitat Enhancement on Mined lands}

\section{Apply the FRA in reclamation; apply all five steps.}

Re-establishing forest plant communities and other ecosystem components on mined lands is more favorable to pollinators than conventional reclamation strategies. The goal of the FRA is to restore, to the extent that is possible, native forest ecosystems on reclaimed mines. Research demonstrates that many components of premining forested ecosystems can be restored successfully on mine sites when all five steps of the FRA are applied: 
1. Create a suitable rooting medium for good tree growth that is no less than $\mathbf{4}$ feet deep and comprised of topsoil, weathered sandstone and/or the best available material;

2. Loosely grade the topsoil or topsoil substitute established in step one to create a non-compacted growth medium;

3. Use ground covers that are compatible with growing trees;

4. Plant two types of trees-early successional species for wildlife and soil stability; and commercially valuable crop trees; and,

5. Use proper tree planting techniques.

\section{When possible, use natural soil that has been salvaged with soil organic matter, roots, and woody debris.}

The FRA's first two steps are to construct a growth medium of at least $\mathbf{4}$ feet in depth using the best available materials, and to use minimal compaction grading techniques on the reconstructed land's surface. Including natural soils with organic debris as part of the growth medium will aid reestablishment of forest plant communities and ecosystem services such as watershed protection in addition to being a superior growth medium for forest trees (Skousen et al. 201 1; Forest

Reclamation Advisory \#8). Use of natural soils with organic debris to construct mine soils is in full accord with the FRA. Freshly salvaged soils contain live roots and seeds that can give rise to plant species that are not seeded, and can enable successful establishment of native plants that enter the site as wind- or wildlife-carried seed. A diverse community of native plants will save the operator planting costs by increasing the number of native trees and ground cover species present during bond release revegetation analysis. These species will also be more favorable pollinator habitat than the restricted and non-native dominated plant communities that often follow conventional reclamation.

In addition to these benefits, we expect that loosely placed spoil materials containing organic debris may provide habitat for ground-dwelling pollinators. Because most North American bees are ground-nesting (NRC 2007), the presence of organic debris in non-compacted mine soils will provide habitat conditions that are more suitable, and more similar to natural conditions than compacted soils constructed of rock spoils. The presence of organic debris in non-compacted mine soils can help maintain soil porosity. Some pollinator species require resources such as dead wood, living plants of specific types, or soil materials for nest-building purposes. All of these can be obtained more readily on reclaimed mines if the reconstructed ecosystems resemble natural systems. Construction of post-mining ecosystems that provide the same ecosystem services as premining ecosystems is intended through application of the FRA.

\section{Seed pollinator-friendly ground cover that will not compete with tree seedlings. Select species to produce a continuous flowering sequence throughout the growing season.}

Step 3 of the FRA calls for the use of ground cover vegetation that balances erosion control and competition for the light, water and space required by trees. Both grasses and broadleaved plants may provide pollinator-friendly and treefriendly habitat. While little scientific research has been conducted to evaluate pollinator-friendly groundcover seeding strategies for reforestation to date, seeding with native herbaceous plants can provide benefit to pollinators (Cusser and Goodell 2013).

Table 1 provides an example of a seed mixture that has been used on mine sites that could serve as a pollinator enhancement to seed mixes already in use. This pollinator-friendly groundcover seed mix could be seeded as presented, or as a mixture with conventional tree-compatible ground cover with the goal of adding native forbs to the seed mix.

Table 1. Example of a pollinator-friendly groundcover seed mix that has been seeded successfully on mine sites.

\begin{tabular}{ll}
\hline Common Name & Lbs./ acre \\
\hline GRASSES & \\
Little Bluestem & $3^{\text {b }}$ \\
FORBS & \\
Lance-leaved Coreopsis & 0.3 \\
Plains Coreopsis & 0.2 \\
Illinois Bundleflower & 0.5 \\
Purple Coneflower & 0.3 \\
Grey-headed Coneflower & 0.3 \\
Partridge Pea & 0.5 \\
Black-eyed Susan & 0.1 \\
Maximilian Sunflower & 0.5 \\
Canada Goldenrod & 0.5
\end{tabular}

\footnotetext{
a Seeding rates on Appalachian mine sites when all are used together. When used in combinations with other tree-compatible groundcovers, these rates can be varied.

${ }^{b}$ grasses/legumes are included in the mix primarily to provide soil stabilization. Rates can vary to meet this goal.
} 
A tree compatible seeding mix which may be used as a starting point for reclamation practitioners as they experiment with additions of flowering plants can be found in Forest Reclamation Advisory No. 6 (Burger et al. 2009). The goal here is to reduce the seeding rates of grasses and legumes by adding a healthy component of native forbs to the mix. As a starting point, we suggest reducing the seeding rate of the current operational mixture to half the current rate, and adding native forbs (Tables 1 and 2). If good vegetation establishment and suitable groundcover are seen over the first year, the grass/legume seeding rate can be further reduced.

To establish conditions most favorable to pollinators, plants are best used in groupings that provide continuous flowering from early spring through late fall. Table 2 lists flowering plants, and their season of flowering. Since the plants listed are all native to the eastern US, we expect that their presence on mine sites during the early stages of reforestation will be compatible with tree seedlings. However, that expectation has not been tested with field trials.

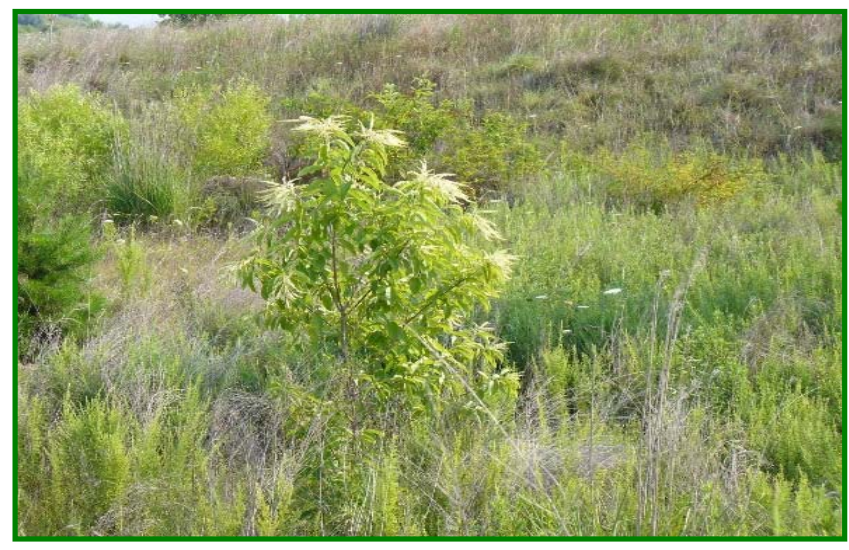

Figure 2. Sourwood sapling blooming in midsummer. Such blooming trees are excellent for mineland reforestation and provide pollinator habitat. Photo by Tammy Horn.

\section{Plant pollinator-friendly tree and shrub species that will produce a continuous flowering sequence through most or all of the growing season.}

FRA Step 4 concerns the selection of tree species for planting. Guidance for tree species selection has been published by Davis et al. (2012) and Rathfon et al. (2015) as Forest Reclamation Advisories Nos. 9 and 13. When applying FRA Step 4, pollinator-friendly tree and shrub species that are adapted to site conditions can be selected (Monteleone et al. 2017). An excellent mix for pollinators will include one or more tree or shrub species that flower and produce large amounts of nectar and/or pollen in the spring, along with one or more species that do so in the summer. An ideal mix would also include a fall-flowering species, such as American witchhazel. Seedlings from most of the tree species listed in Table 2 are easily available from commercial nurseries.

\section{Consider tree and ground cover species together when designing a pollinator- friendly reclamation strategy.}

The flowering sequence of herbaceous and woody plants can be considered together. For example, very few fall-flowering tree species are available for mine plantings. However, the Canada goldenrod, which grows well in full sun and partial shade, is highly persistent, beneficial to pollinators, and produces fall flowers. Another fall-flowering native species, favorable to pollinators, that persists in partial shade is yellow crownbeard. However, neither of these species have been tested for compatibility with growing trees on reclaimed surface mines. By considering flowering sequences of both ground cover and tree/shrub species, the goal of season-long flowering can be achieved. Further research can clarify how groundcover and trees interact when used in pollinator plantings.

\section{Commercial Bee and Honey Production on Mine Sites}

Reclaimed-mine forests with pollinator-friendly plant species can support commercial bee and honey production as well as robust native pollinator communities. There are many examples of initiatives to establish beekeeping enterprises on mined lands. In 1976, the University of Kentucky, Tennessee Valley Authority and Peabody Coal developed a collaborative honey production project on reclaimed surface mined land in Muhlenberg County in western Kentucky (Angel and Christiansen 1976). More recently, commercial beekeepers collaborated with coal companies to develop pollination yards on their surface mine sites (Figure 3; Horn 2012). In addition to using the FRA, the four coal companies agreed to provide understory trees, such as sourwood, and wildflowers that are particularly honey bee friendly. Working with Virginia Cooperative Extension in Wise County, Virginia, local beekeepers have maintained and operated hives for honey production on mine sites at Powell River Project since 2010. In 2015, West Virginia, a state with large amounts of surface mine land that can be turned into pollinator-friendly forests, launched a program to train veterans on how to keep bees and produce honey. Guidelines for siting apiaries on reclaimed mine lands are presented in Box 1. 


\section{Summary}

Many pollinator species are under threat worldwide for many reasons, including habitat loss. In Appalachia, native forests serve as pollinator habitat. This Advisory describes methods for re-establishing pollinator habitat on coal surface mines by reforesting mine sites using the FRA. We recommend that the FRA be applied in a manner that will produce soil conditions on mine sites similar to those of unmined forests. We also recommend establishing a diverse community of seeded and naturally invading native plants; and re-establishing native plant species that will provide a continuous bloom cycle throughout the growing season.

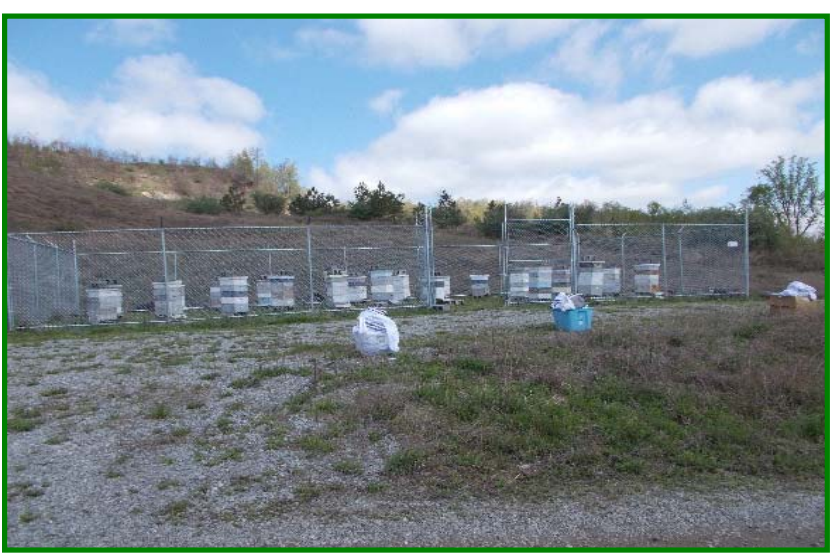

Figure 3. Apiary site on a reforested mineland in Kentucky. Photo by Tammy Horn.

Table 2. Flowering herbaceous plants that are native to the eastern US that can be used as part of a pollinator-friendly groundcover seed mix, such as that described by Table 1. A minimum of 6 different flowering plants should be included in the mix. The utility of these species with tree-compatible seeding mixes recommended for use with the FRA has not yet been tested.

\begin{tabular}{lll}
\hline Common Name & Scientific Name & Flowering season $\neq$ \\
\hline Beggarticks & Bidens alba & Spring \\
Lance-leaved Coreopsis & Coreopsis lanceolata & Spring \\
Plains Coreopsis & Coreopsis tinctoria & Spring \\
Illinois Bundleflower & Desmanthus illinoensis & Late spring - summer \\
Purple Coneflower & Echinacea purpurea & Late spring - summer \\
Grey-headed Coneflower & Ratibida pinnata & Late spring - \\
Yarrow & Achillea millefolium & summer \\
Common Milkweed & Asclepias syriaca & Spring - summer \\
Wild Bergamot & Monarda fistulosa & Summer \\
Partridge Pea & Chamaecrista fasciculata & Summer - early fall \\
Black-eyed Susan & Rudbeckia hirta & Summer - early fall \\
Boneset & Eupatorium perfoliatum & Summer - early fall \\
Maximilian Sunflower & Helianthus maximiliani & Fall \\
Canada Goldenrod & Solidago canadensis & Fall \\
Yellow Crownbeard & Verbesina occidentalis & Fall \\
\hline
\end{tabular}

${ }^{\ddagger}$ As per NPIN, Native Plant Information Network, www.wildflower.org. Additional information on plant species being considered for seeding can be found at http://plants.usda.gov/ and in Hopewood and others (2015). 
Table 3. Tree and shrub species that can be used with the FRA to provide flowers for pollinators.

\begin{tabular}{|c|c|c|}
\hline Common name & Scientific Name & Flowering Season \\
\hline Eastern Redbud & Cercis canadensis & Early spring \\
\hline $\begin{array}{l}\text { Serviceberry } \\
\text { Washington Hawthorn } \\
\text { Red Maple }\end{array}$ & $\begin{array}{l}\text { Amelanchier spp. } \\
\text { Crataegus phaenopyrum } \\
\text { Acer rubrum }\end{array}$ & $\begin{array}{l}\text { Early spring } \\
\text { Early spring - early summer } \\
\text { Early spring }\end{array}$ \\
\hline Sugar Maple & Acer saccharum & Early spring \\
\hline $\begin{array}{l}\text { Willows } \\
\text { Black Chokeberry } \\
\text { Red Mulberry } \\
\text { Nannyberry } \\
\text { Tulip Poplar }\end{array}$ & $\begin{array}{l}\text { Salix spp. } \\
\text { Aronia melanocarpa } \\
\text { Morus rubra } \\
\text { Viburnum lentago } \\
\text { Liriodendron tulipifera }\end{array}$ & $\begin{array}{l}\text { Spring } \\
\text { Spring } \\
\text { Spring } \\
\text { Late spring } \\
\text { Late spring - early summer }\end{array}$ \\
\hline Black Locust & Robinia pseudoacacia & Late spring - early summer \\
\hline Persimmon & Diospyros virginiana & Late spring - early summer \\
\hline Basswood & Tilia americana & Early-mid summer \\
\hline $\begin{array}{l}\text { Sourwood } \\
\text { Gray Dogwood } \\
\text { American Chestnut }\end{array}$ & $\begin{array}{l}\text { Oxydendron arboreum } \\
\text { Cornus racemosa } \\
\text { Castanea dentata }\end{array}$ & $\begin{array}{l}\text { Mid-summer } \\
\text { Summer } \\
\text { Summer }\end{array}$ \\
\hline American Witchhazel & Hamamelis virginiana & Fall \\
\hline
\end{tabular}

${ }^{\dagger}$ includes genetically improved hybrids, as described by French et al. (2015).

BOX 1: Locating apiaries on reforested surface mines.

Owners of land that has been surface mined and reclaimed with the FRA and pollinator-friendly plants have opportunities to use them for honey production. Similarly, for owners of legacy surface mines that have been mitigated and reforested with 'honey plants,' beekeeping can provide extra income and unique educational experiences (right). Landowners can also promote pollinators by providing experienced beekeepers with access to their nectar- and pollen resources on reforested surface mined land. Groups of honey bee hives (called apiaries) can be located almost anywhere on a mine site or on property adjacent to a mine site, but choosing the best possible location increases the chances for the development of strong colonies and successful honey production.

Here are some points to consider when locating an apiary on a reforested surface mine:

- Locate the apiary as close as possible to good nectar and pollen sources. Honey bees will fly two miles in any direction to find what they need to survive, and in times of stress, can fly up to five miles.

- Honey bees need to be located near a water source because they use water to regulate the temperature of the hive and to create liquid food for larvae. The water source does not have to be crystal-clear. Honey bees will collect minerals from muddy ponds used by cattle.

- Windbreaks may be needed to provide protection from cold winds in the winter.

- Since bad weather tends to come from west to east, place bee hives so that they face to the east or south.

- In hilly terrain, it is better to locate bee hives at the bottom of a slope instead of on top of a slope since bees fly uphill to forage and downhill when loaded with nectar and pollen.

- Avoid locating hives near large sediment ponds since bees could fall into the water and drown when returning back to the hive loaded down with nectar.

- Erect a solar powered electric fence around the apiary if bears are a potential threat. It is a good idea to erect a fence before moving hives to an area instead of after.

- To minimize vandalism or theft, the apiary should be located in an area that is naturally hidden from view from access roads, water impoundments, etc. Apply a camouflaged paint pattern to the bee hives. Road access to the apiary should be controlled by a strong gate.

Numerous resources are available to beginner or expert beekeepers to learn more about apiculture such as books, the internet, beekeeping suppliers, local or state clubs. Contact your State Cooperative Extension Service, Natural Resources Conservation Service (NRCS) or State Apiarist for guidance and more information. 


\section{Literature cited}

Angel P.N. and C.M. Christensen. 1976. Honey Production on Reclaimed Strip Mine Soil. p. 708-71 1, in: Hill Lands: Proceedings of an International Symposium. West Virginia University, Morgantown.

Burger J.A., V. Davis, J. Franklin, J. Skousen, C. Barton, C.E. Zipper. 2009. Tree-compatible ground covers for reforestation and erosion control. ARRI Forest Reclamation Advisory No. 6. 6 p.

Burger J.A., D. Graves, P. Angel, V. Davis, C.E. Zipper. 2005. The forestry reclamation approach. ARRI Forest Reclamation Advisory No. 2. 4 p.

Calderone N.W. 2012. Insect Pollinated Crops, Insect Pollinators and US Agriculture: Trend Analysis of Aggregate Data for the Period 1992-2009. PLoS ONE 7(5): e37235. doi:10.1371/journal.pone.0037235

Cane J.H., V.J. Tepedino. 2001. Causes and extent of declines among native North American invertebrate pollinators: detection, evidence, and consequences. Conservation Ecology 5 (1).

Cusser S., K. Goodell. 2013. Diversity and distribution of floral resources influence the restoration of plant-pollinator networks on a reclaimed strip mine. Restoration Ecology 21: 713-721.

Davis V., J.A. Burger, R. Rathfon, C.E. Zipper, C.R. Miller. 2012. Selecting Tree Species for Reforestation of Appalachian Mined Lands. ARRI Forest Reclamation Advisory No. 9. 8 p.

Drummond, M., and T. Loveland. 2010. Land-use pressure and a transition to forest-cover loss in the eastern United States. Bioscience 60:286-298.

French M., C. Barton, B. McCarthy, C. Keiffer, J. Skousen, C. Zipper, P. Angel. Re-establishing American Chestnut on Mined Lands in the Appalachian Coalfields. Forest Reclamation Advisory No. 12.

Goulson D., E. Nicholls, C. Botias, E. Rotheray. Bee declines driven by combined stress from parasites, pesticides, and a lack of flowers. Science 347: 1435.

Hanula J.L., M.D. Ulyshen, S. Horn, S., 2016. Conserving pollinators in North American forests: A review. Natural Areas Journal 36: 427-439.

Hopewood, J., S. Black, S. Fleury. 2015. Roadside Best Management Practices that Benefit Pollinators: Handbook for Supporting Pollinators through Roadside Maintenance and Landscape Design. Report FHWA-HEP-16-059. U.S. Department of Transportation, Federal Highway Administration. Washington D.C. 88 p.

Horn 2012. Beeconomy: What Women and Bees Can Teach Us about Local Trade and the Global Market. Lexington, KY: University Press of Kentucky. 392 p.

Kearns, C.A., D.W. Inouye. 1997. Pollinators, flowering plants, and conservation biology. Bioscience 47: 297-307.

Moisset B., S. Buchmann. 2011. Bee Basics: An Introduction to Our Native Bees. U.S. Department of Agriculture, Forest Service. http://www.fs.usda.gov/Internet/FSE_DOCUMENTS/stelprd b5306468.pdf

Monteleone, A., J. Skousen, L. McDonald, J. Shuler, J. Pomp, M. French, and R. Williams. 2017. Evaluation of small tree and shrub plantings on reclaimed surface mines in West Virginia. J. Amer. Soc. Mining Recl. 6: in press.

Native Plant Information Network. 2016. Native Plant Database. https://www.wildflower.org/plants/
National Research Council (NRC). 2007. Status of Pollinators in North America. National Academy of Sciences, National Academies Press. Washington DC. $326 \mathrm{p}$.

Oliphant A.J., R.H. Wynne, C.E. Zipper, W.M. Ford, P.F. Donovan, J. Li. 2016. J., Autumn olive (Elaeagnus umbellata) presence and proliferation on former surface coal mines in Eastern USA. Biological Invasions, pp. 1-17.

Ollerton J., R. Winfree, S. Tarrant. 2011 . How many flowering plants are pollinated by animals? Oikos 120: 321-326.

Potts, S.G., J.C. Biesmeijer, C. Kremen, P. Neumann, O. Schweiger, W. E. Kunin. 2010. Global pollinator declines: trends, imapcts and drivers. Trends in Ecology and Evolution 25:6. p. 345-353.

Rathfon, R. J. Groninger, D. Jacobs, J. Burger, P. Angel, C. Zipper. 2015. Tree and shrub species selection for mine reclamation in the midwest region of USA. Forest Reclamation Advisory No. 13. Appalachian Regional Reforestation Initiative, US Office of Surface Mining.

Sayler, K.L. 2008. Land cover trends: Central Appalachians. U.S. Department of the Interior, U.S. Geological Survey. Available at http://landcovertrends. usgs.gov/east/eco69Report.html

Skousen J., C.E. Zipper, J. Burger, C. Barton, P. Angel. 2011. Selecting materials for mine soil construction when establishing forests on Appalachian mine sites. ARRI Forest Reclamation Advisory No. 8. 6 p.

U.S. Natural Resource Conservation Service. 2016. Plants Database. http://plants.usda.gov/

Zipper, C.E., J.A. Burger, J.M. McGrath, J.A. Rodrigue, G.I. Holtzman. 2011 . Forest restoration potentials of coal-mined lands in the eastern United States. Journal of Environmental Quality 40: 1567-1577.

\section{Acknowledgements}

Faculty and researchers from the following universities and organizations contributed to this Forest Reclamation Advisory: American Bird Conservancy, Berea College, Green Forests Work, Indiana University of Pennsylvania, Ohio State University, Ohio University, Pennsylvania State University, Purdue University, Southern Illinois University, Stephen F. Austin State University, The American Chestnut Foundation, US Forest Service, US Geological Survey, US Office of Surface Mining Reclamation and Enforcement, University of Kentucky, University of Maryland, University of Tennessee, Virginia Tech, West Virginia University, and Wilkes University.

\section{Authors}

Tammy Horn (Tammy.horn@ky.gov), State Apiarist for Kentucky, Frankfort, KY.

Patrick Angel (pangel@osmre.gov), Office of Surface Mining, U.S.D.I., London KY.

Carl Zipper (czip@vt.edu), Virginia Tech, Blacksburg VA.

Michael Ulyshen (mulyshen@fs.fed.us), USDA Forest Service, Southern Research Station, Athens, GA.

Michael French (michael.french@acf.org) Green Forests Work, American Chestnut Foundation, Hope, IN.

Jim Burger (jaburger@vt.edu) Virginia Tech, Blacksburg, VA.

Mary Beth Adams (mbadams@fs.fed.us), USDA Forest Service, Morgantown, WV. 